\title{
Internet-based interventions to support recovery and self-management: $A$ scoping review of their use by mental health service users and providers together
}

Anne Williams $s^{1,2^{*}}$, John Farhall ${ }^{3,4}$, Ellie Fossey ${ }^{5,6}$ and Neil Thomas $s^{7,8}$

\begin{abstract}
Background: Internet-based interventions can make self-management and recovery-oriented information and tools more accessible for people experiencing severe mental illness, including psychosis. The aim of this scoping review was to identify and describe emerging joint uses of these Internet-based interventions by service users experiencing psychosis and mental health workers. It also investigated how using these Internet-based interventions influenced interactions between service users and workers and whether recovery-oriented working practices were elicited.

Methods: A scoping review method was used. Iterative review stages included identifying the review question, a comprehensive search including searching six electronic databases to locate relevant studies, selecting studies, charting the data, and collating and reporting the results. Rigour of the scoping review was enhanced by using an appraisal tool to evaluate the quality of included studies, and by using a published template for systematic description of interventions.

Results: Fifteen papers about eleven Internet-based interventions that focused on self-management and/or recovery were identified. Interventions were web-based, mobile-device based, or both. The eleven interventions were used by service users either with their usual mental health workers, or with mental health workers employed in a research project. Emerging evidence suggested that jointly using an Internet-based intervention could support a positive sense of working together. However, mismatched expectations and poor integration of Internet-based interventions into service systems could also negatively influence interactions, leading to mistrust. The interventions demonstrated potential to elicit recognised recovery-oriented practices, specifically understanding service users' values and supporting their goal striving.

Conclusions: The use of Internet-based interventions focused on self-management and recovery in mental health services by service users and workers jointly demonstrates potential to support working together and recovery-oriented practice. Given that the quality of relationships is critical in recovery-oriented practice, greater focus on human support in Internet-based interventions is needed in future research and practice.
\end{abstract}

Keywords: Internet, mental health, mental health services, psychosis, recovery-oriented practice, self-management, severe mental illness

\footnotetext{
* Correspondence: annewilliams@swin.edu.au;

williams.ae@students.latrobe.edu.au

'Department of Occupational Therapy, Social Work and Social Policy, La

Trobe University, Melbourne, Victoria, Australia

${ }^{2}$ Department of Health Professions, Swinburne University of Technology,

Hawthorn, Victoria, Australia

Full list of author information is available at the end of the article
}

(c) The Author(s). 2019 Open Access This article is distributed under the terms of the Creative Commons Attribution 4.0 International License (http://creativecommons.org/licenses/by/4.0/), which permits unrestricted use, distribution, and reproduction in any medium, provided you give appropriate credit to the original author(s) and the source, provide a link to the Creative Commons license, and indicate if changes were made. The Creative Commons Public Domain Dedication waiver (http://creativecommons.org/publicdomain/zero/1.0/) applies to the data made available in this article, unless otherwise stated. 


\section{Background}

People who live with a diagnosis of a severe mental illness (SMI) often experience enduring mental, physical, social and economic impacts from their illness experience and are high users of mental health services [1]. This includes people described in the literature as experiencing schizophrenia and related diagnoses, affective mental illnesses with psychotic symptoms, and other psychotic disorders [1]. In line with a gradual reorientation of health services towards health promotion [2], mental health services targeted at people experiencing SMI increasingly aim to deliver services that move beyond clinical treatment and crisis management [3]. Current imperatives include supporting service users experiencing SMI in their individual recovery journeys [3-5] and enabling them to self-manage their physical and mental health [2]. Supporting service users in their personal recovery, defined as leading an individually determined meaningful and productive life in the context of living with a mental illness [6,7], has become a mental health service priority [3]. The related focus on self-management repositions service users experiencing SMI as active participants in their treatment and provides tools that can empower them to have the confidence to manage their health over time, thus supporting their ongoing recovery journey [2].

Internet-based interventions have potential to enhance mental health services, including by supporting selfmanagement and recovery among people experiencing severe mental illness [8]. This population is using the Internet and interested in Internet-based interventions [9-12]. Types of interventions delivered via the web and mobile devices include psychoeducation, illness monitoring and management tools, communication and decision-making tools and peer support [13-15]. For example, in their review of remotely delivered mHealth and eHealth interventions, Naslund et al. [15] included messaging services targeting illness self-management; websites with education, coping skills tools and peer support; and activity trackers connected to a smartphone app designed to increase physical activity. These interventions may be designed specifically for people experiencing SMI by incorporating simple visual designs and customised reading and abstract reasoning demands [15]. One way to categorize the broad range of Internetbased interventions currently available is as either webbased (for example, websites, discussion rooms and Internet diaries accessed via the Internet on a computer or other device), or mobile device-based (for example, text messaging or applications used on a smartphone or other mobile device) [13].

Numerous reviews indicate that Internet-based interventions are feasible and acceptable for people experiencing SMI [16-20], with promising signs of their efficacy [13, 17, 19]. Identified benefits of web-based and mobile-device based interventions include supporting users' treatment engagement, building their selfmanagement and coping skills, increasing their knowledge about their illness, improving symptom management and preventing relapse [8,13-15]. These findings have been welcomed given the accessability, potential for anonymity and cheaper cost of delivering Internet interventions compared to interventions delivered face-toface [13]. Internet interventions are expected to continue to develop and become more widely available to people experiencing SMI in the future $[14,15,19,21]$.

There are potential challenges to integrating Internetbased interventions for self-management and recovery into usual mental health services for people experiencing SMI. van der Krieke et al. [19] argue that a focus on symptom monitoring in many Internet-based selfmanagement interventions makes a personal recovery approach difficult, by reproducing "an outdated paternalistic paradigm of patient-clinician interaction in which compliance and monitoring are the aim" (p. 4647). Additionally, Villani and Kovess-Masfety [12] identified that people experiencing psychotic disorders may perceive that raising treatment information from the Internet with their doctor could negatively impact their relationship, if the doctor feels criticized. In considering future challenges, Álvarez-Jiménez et al. [14] propose that "Internet-based interventions for psychosis that are specifically designed to supplement existing mental health services and augment traditional relationships through online interaction... are likely to be the most beneficial" (p.742). However, others have noted that engaging service users $[19,21]$ and workers $[21]$ in these interventions may be difficult. In sum, integrating Internet-based interventions into mental health services is likely to be complex, and attention will need to be paid to how relationships between service users and their mental health workers might best work in a digital environment.

The quality of relationships between service users and workers is core to recovery-oriented practice [22, 23] and to facilitating partnerships that support selfmanagement [2], yet the place of professional supervision and support in Internet-based interventions is considered infrequently [13] and the impact of the interventions on working relationships has received little attention. One review by Strand et al. [24] considered the extent to which Internet-based interventions integrated into ongoing mental health care supported recovery-oriented practice domains as defined by Le Boutillier et al. [3], including recovery-promoting relationships. Their review included six interventions published up to May 2015, which were used with people experiencing long-term mental health problems. Strand et al. [24] concluded that while these interventions 
supported work in which recovery was personally defined by service users, it was less clear whether using the interventions supported recovery-promoting relationships or inspired hope [24]. Further investigation of how jointly using an Internet-based intervention can influence working relationships is therefore needed. The aim of this scoping review was to conduct a systematic search of the literature to identify and describe joint uses of Internet-based interventions focused on recovery and/ or self-management, by service users experiencing SMI and mental health providers, and to explore how these interventions influence their interactions.

\section{Methods}

\section{Scoping review methodology}

A scoping review method involving five stages [25-27] was selected to explore the range of research activity in this area of mental health practice and to address questions that go beyond intervention effectiveness [26]. We also adopted Daudt et al.'s [28] recommendation to assess the quality of studies included in scoping reviews.

\section{Stage 1: Identifying the review question}

The review questions comprised:

1. What Internet-based interventions (web-based or mobile-device based) with a recovery and/or selfmanagement focus are service users experiencing SMI, specifically psychosis, and mental health workers using within mental health services?

2. How does using these Internet-based interventions influence interactions between these service users and workers?

3. Does using Internet-based interventions focused on recovery or self-management elicit recoveryoriented working practices?

\section{Stage 2: Identifying relevant studies}

The literature search was guided by Atkinson et al. [29] to enhance its transparency. Six electronic databases were searched from 2005 to March 2016: The Cochrane Library; Embase (Ovid); Cumulative Index to Nursing and Allied Health Literature (CINAHL) (Ebsco); Computer Database (Gale); Medline (Ovid); and PsychINFO (Ovid). The search period reflected that earlier Internetbased interventions were designed for people experiencing anxiety and depression, not SMI $[17,19,20]$. A university librarian reviewed and approved the search strategy, followed by the first author conducting the database searches using the key words shown in Table 1, modified as necessary for specific databases.

Additional searching included tracking citations in reviews that were found in the searches but did not meet the inclusion criteria, and in the included studies; a Google Scholar alert (running to Dec 31, 2017); and a grey literature search of ProQuest Dissertations, Theses Global, SCOPUS Proceedings, BMC Proceedings and the Grey Literature Report. Key word searches were conducted in six relevant journal titles including the Journal of Medical Internet Research Mental Health and Psychiatric Services. Finally, database searches in Medline, CINAHL and Embase were updated to December 2017. A total of 558 citations, excluding duplicates, were identified. Figure 1 outlines the study selection process.

\section{Stage 3: Study selection}

The first author reviewed titles and abstracts against inclusion and exclusion criteria that were iteratively refined as recommended [26, 27], in consultation with authors two and four. The second author independently reviewed $10 \%$ of randomly selected titles and abstracts. High levels of agreement were recorded on title (93\%) and abstract (80\%) decisions and any disagreements were resolved by consensus. As shown in Fig. 1, 323 irrelevant titles were removed when it was clear from the title that the study did not involve an Internet-based intervention, or participants who experienced psychosis, or both. A further 107 studies were excluded after reading the abstract clarified that they also did not meet the inclusion criteria.

Table 1 Search terms, inclusion and exclusion criteria

\begin{tabular}{|c|c|c|c|}
\hline & Key search terms & Inclusion criteria & Exclusion criteria \\
\hline Population & $\begin{array}{l}\text { Severe mental illness } \\
\text { Serious mental illness } \\
\text { Schizophrenia } \\
\text { Psychotic disorders } \\
\text { Psychotic illness }\end{array}$ & $\begin{array}{l}\text { Adults experiencing SMI including psychotic illness } \\
\text { or mental illnesses with psychotic features }\end{array}$ & $\begin{array}{l}\text { Solely high prevalence mental health conditions } \\
\text { including anxiety, depression } \\
\text { Solely bipolar disorder or major depression where } \\
\text { presence of psychosis is unclear }\end{array}$ \\
\hline Intervention & $\begin{array}{l}\text { Internet-based } \\
\text { intervention } \\
\text { Internet web-based } \\
\text { eHealth, mHealth } \\
\text { Online }\end{array}$ & $\begin{array}{l}\text { Primary: Service user and mental health worker } \\
\text { engaged in the intervention, whether synchronously } \\
\text { or asynchronously } \\
\text { Secondary: Service user and research personnel in } \\
\text { mental health service engaged in the intervention }\end{array}$ & $\begin{array}{l}\text { Intervention does not engage both service user } \\
\text { and mental health worker or research personnel } \\
\text { Stand-alone computer-mediated intervention } \\
\text { (no web-based or mobile-device based component) }\end{array}$ \\
\hline Outcome & $\begin{array}{l}\text { Recovery } \\
\text { Self-management } \\
\text { Illness management }\end{array}$ & $\begin{array}{l}\text { Interventions that aim to support personal recovery } \\
\text { and/or self-management }\end{array}$ & $\begin{array}{l}\text { Interventions that focus solely on clinical recovery } \\
\text { such as symptom reduction or treatment compliance }\end{array}$ \\
\hline
\end{tabular}


Records identified through database searching

( $n=511: 449$ first search; 62 in update)
Additional records identified through other sources $(n=136)$

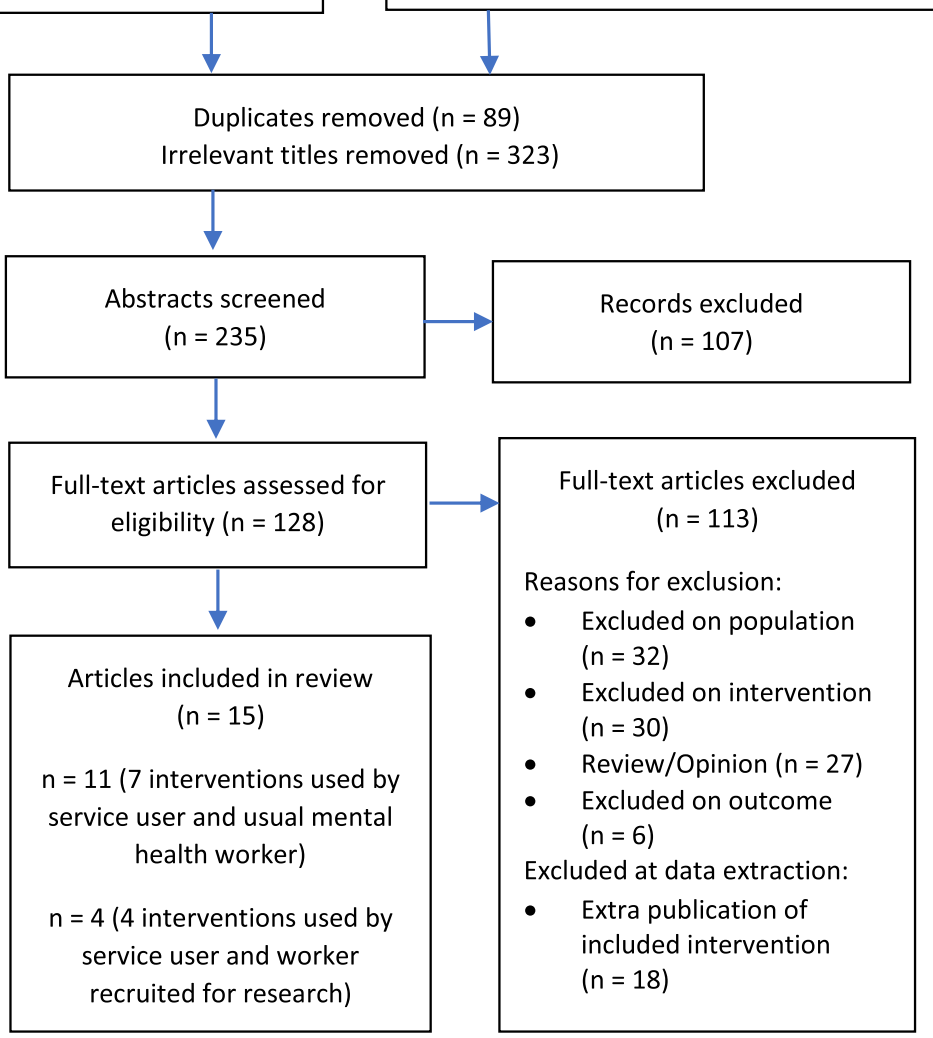

Fig. 1 Flow chart of study selection process

We reviewed the full text of the remaining 128 studies (Fig. 1). The first and second authors met regularly during this phase to review papers and to reach consensus on studies that met the inclusion criteria. Thirty-two studies were excluded at the full text stage, as on review the population did not clearly include people who experienced SMI. We defined jointly using an Internet-based intervention as occurring when the pair engaged with the intervention, including communicating through and/ or about the intervention, whether synchronously or asynchronously. Thirty studies were excluded as not meeting the intervention inclusion criteria. Examples included workers interacting with an online community, rather than having one-to-one working relationships with service users (e.g. [30]), and computer-mediated interventions without a web-based or mobile device-based component, such as electronic decision support systems [31, 32]. We included studies of Internet-based shared decision making (SDM) tools, given that sharing decisions about treatment requires a partnership between a service user and provider and supports the process of "recovering a life after a diagnosis of a major mental disorder" [33]. Other studies were excluded if they were review or opinion articles not directly relevant to the population and intervention, if outcomes addressed in the study were clinical, such as treatment compliance, or when there were multiple studies about the same intervention and population that did not add further information to studies that were already included (Fig. 1).

Fifteen studies remained after we applied the clearly defined inclusion criteria. We distinguished between primary studies $(n=11)$, in which an Internet-based intervention was used within an existing service user-provider working relationship, and secondary studies $(n=4)$, where research workers were employed to provide the intervention.

\section{Stage 4: Charting the data}

The quality of included studies was appraised to support the dissemination of useful scoping review findings [28]. The first author appraised the included studies using the Mixed Methods Appraisal Tool (MMAT-v2011) [34, 35], an efficient tool to appraise diverse study designs [36, 37]. Each study appraisal was converted to an overall quality score from low (0) to high (4 points). Second, to answer 
review questions 1 and 3, the first author extracted descriptive data and relevant findings. The Template for Intervention Description and Replication (TIDieR checklist) [38] was used to document each intervention. Extra publications describing the development of the interventions were consulted to add further detail. An additional text file provides this information (Additional file 1). The relatively small number of included studies and regular reviewer consultation during this phase negated the need for independent data extraction.

\section{Stage 5: Collating, summarizing and reporting results}

Next, extracted data were collated and summarized as suggested $[25,26]$ into a descriptive and narrative summary of study characteristics that addressed the first and third review questions. Three specific recovery-oriented working practices were considered to answer the third question: understanding service users' values; assessing and amplifying their strengths; and supporting goal striving [23, 39]. The first author completed a qualitative data-driven thematic analysis [40] to answer the second review question. Qualitative findings related to interactions between service users and mental health workers when using an Internet-based intervention were coded in qualitative software as recommended by Levac et al. [26], using QSR's International NVivo 11 data analysis software [41]. The coding process was recorded in a memo and reviewed with the third author. All authors contributed to reporting the summarized results.

\section{Results}

The results are presented in three sections: first a summary of characteristics and quality of the included studies is provided. Second, to answer the first review question, the Internet-based interventions that were the focus of these studies are outlined, presented separately for interventions used with a usual mental health worker and those used with a research worker. The third section considers the influence of jointly using an Internet-based intervention on mental health practice to answer research questions two and three.

\section{Summary of included studies Study characteristics}

The 15 included papers outlined 11 Internet-based interventions used in mental health services in Europe (5 interventions), North America (5 interventions) and Australia (1 intervention) by service users and mental health workers. Seven interventions engaged service users and their usual mental health workers [42-52] (Table 2). Of these, two publications were included for the Mieli.Net [42, 43], Mental Health Engagement Network (MHEN) [45, 46], CommonGround [47, 48] and ReConnect [51, 52] interventions. Four interventions engaged experienced mental health workers employed in a research project [53-56] (Table 3). The mental health workers were most commonly psychiatric nurses in community health settings, however social workers, occupational therapists, psychologists, psychiatrists and peer workers also participated. All interventions included web-based elements such as websites, online forums and Internet diaries. Five also incorporated mobiledevice based interventions in the form of native smartphone apps $[45,49,53,55,56]$. People with lived experience of mental illness were described as having explicit researcher roles in the Momentum [49] and ReConnect [52] studies only.

\section{Study quality}

All studies were exploratory in nature, including five qualitative, five mixed-methods and five quantitative studies (Tables 2 and 3). Methodological quality using the MMAT-v2011 tool [35] varied considerably. Qualitative studies were rated from 0 to 4 points, quantitative from 1 to 4 points and mixed methods studies from 0 to 2 points. The mixed methods ratings were lower as their scores are determined by the lowest score of either the qualitative or quantitative component [35].

Descriptions of study quality based on the MMAT-v2011 can provide more useful information than the scores, given that the quality of reporting different study designs varies [35]. A strength of the qualitative studies and qualitative components of mixed methods studies was sourcing information-rich participants' experiences. However, qualitative data from both service users and workers were collected in less than half $(40 \%)[44,45,47-49,51,52]$ of the 15 studies. Ratings for the qualitative studies were also limited by researchers minimally considering their influence on the qualitative findings, other than in ReConnect [52]. The quantitative studies and quantitative components of mixed methods studies reported predominantly descriptive data on use of and satisfaction with the interventions. This included feasibility and acceptability research for a sample of 200 participants (HTP) [53], and three small samples (n $\leq 20)$ (PeerTECH, SMART, PRIME) [54-56]. There was also one mixed methods study with 400 service user and 54 worker participants [45]. Using the MMAT-v2011 [35] criteria, a strength was that quantitative measures used in the studies were usually described clearly and standardized (for example, to measure quality of life or empowerment). Ratings were reduced by missing information about the study sample, such as justification of the sample size or why eligible participants chose not to participate.

\section{Outline of Internet-based interventions}

Key details of the intervention goals, tools and use are summarised below, to provide an outline of the types of Internet-based interventions that were the focus of each 
Table 2 Study characteristics: Interventions used with usual mental health worker

\begin{tabular}{|c|c|c|c|c|c|}
\hline Study & Design/MMAT Rating & Setting/Country/Year & Intervention & Service users/ diagnosis & Workers/ profession \\
\hline $\begin{array}{l}\text { Koivunen, } \\
\text { Huhtasalo } \\
\text { [43] }\end{array}$ & $\begin{array}{l}\text { Qualitative description: } \\
\text { worker questionnaires } \\
\text { after } 12 \text { months using } \\
\text { intervention } 2 / 4 \\
\text { Qualitative description: } \\
\text { worker FGs and } 1: 1 \mathrm{IVs} \\
\text { after providing systematic } \\
\text { IT education } 2 / 4\end{array}$ & $\begin{array}{l}\text { Two inpatient } \\
\text { psychiatric hospitals, } \\
\text { Norway, 2005-2006 }\end{array}$ & $\begin{array}{l}\text { Mieli.Net } \\
\text { WB: patient education } \\
\text { portal to support SM. } \\
\text { Includes information, } \\
\text { peer and staff support } \\
\text { channels. Nurses used } \\
\text { portal to deliver } 6 \\
\text { education sessions over } 1 \\
\text { month. SU continued } \\
\text { access post discharge. }\end{array}$ & $\begin{array}{l}n=\text { undisclosed } \\
\text { Available to inpatients } \\
\text { diagnosed with } \\
\text { schizophrenia }\end{array}$ & $\begin{array}{l}n=30 \text { (subset of above) } \\
14 \text { nurses provided IT } \\
\text { based education and } 16 \\
\text { provided conventional } \\
\text { education }\end{array}$ \\
\hline $\begin{array}{l}\text { de Leeuw, } \\
\text { van Splunteren } \\
{[44]}\end{array}$ & $\begin{array}{l}\text { Mixed methods }^{\mathrm{a}} \\
\text { Single group pilot study: } \\
\text { qualitative results only. SU } \\
\text { and worker open-ended } \\
\text { questions at BL and after } \\
9 \text { months; and FGs at } 15 \\
\text { months. O/4 }\end{array}$ & $\begin{array}{l}\text { Two MH } \\
\text { organizations, } \\
\text { Netherlands, } \\
\text { 2009-2011 }\end{array}$ & $\begin{array}{l}\text { Personal Control in } \\
\text { Rehabilitation (PCR) } \\
\text { WB: SM \& } \\
\text { communication } \\
\text { portals including } \\
\text { information, SM, } \\
\text { communication } \\
\text { tools. SU could } \\
\text { authorize worker } \\
\text { and carer access. }\end{array}$ & $\begin{array}{l}n=19 \text { (FG participants); } \\
100 \% \text { schizophrenia or } \\
\text { first episode psychosis; } \\
74 \% \text { male; aged } 16-66 \\
\text { years }\end{array}$ & $\begin{array}{l}n=36 \\
15 \text { nurses, } \\
8 \text { psychiatric nurses, } \\
4 \text { SW, } 3 \text { psychologists, } \\
3 \text { psychiatrists, } 3 \\
\text { managers }\end{array}$ \\
\hline $\begin{array}{l}\text { Forchuk, } \\
\text { Rudnick } \\
\text { [45] }\end{array}$ & $\begin{array}{l}\text { Mixed methods, Initial } \\
\text { analysis of data from } \\
\text { two group, delayed } \\
\text { intervention RCT. SU } \\
\text { questionnaire at BL, } 6 \text {, } \\
12,18 \text { months and usage } \\
\text { data. SU and worker FGs } \\
\text { held over } 18 \text { months } 0 / 4\end{array}$ & $\begin{array}{l}\text { Four community } \\
\text { MH agencies, } \\
\text { Canada, 2012-2014 }\end{array}$ & $\begin{array}{l}\text { Mental health } \\
\text { engagement } \\
\text { network (MHEN)WB } \\
\text { and MDB: App } \\
\text { with personal } \\
\text { health record } \\
\text { and SM tools. } \\
\text { Smart phone }\end{array}$ & $\begin{array}{l}n=400 \\
59 \% \text { Psychotic disorder; } \\
60 \% \text { male; mean age } \\
37 \text { years }\end{array}$ & $\begin{array}{l}n=54 \\
\text { Nurses, SW, OT }\end{array}$ \\
\hline $\begin{array}{l}\text { Forchuk, } \\
\text { Donelle } \\
{[46]}\end{array}$ & $\begin{array}{l}\text { Mixed methods, SU } \\
\text { questionnaires, and FG } \\
\text { data as illustrative } \\
\text { quotes } 1 / 4\end{array}$ & & $\begin{array}{l}\text { provided to SU; } \\
\text { tablet device } \\
\text { provided to } \\
\text { workers for both } \\
\text { to access health } \\
\text { record. }\end{array}$ & $\begin{array}{l}n=394 \text { (same sample } \\
\text { as above) }\end{array}$ & \\
\hline $\begin{array}{l}\text { Goscha } \\
\text { and Rapp } \\
{[47]}\end{array}$ & $\begin{array}{l}\text { Qualitative description: } \\
2 \times 1: 1 \mathrm{SU} \text { and worker } \\
\text { IVs after } 4 \text { months } \\
\text { intervention use } 3 / 4\end{array}$ & $\begin{array}{l}\text { One community } \\
\text { MH centre, Kansas, } \\
\text { USA 2006-2007 }\end{array}$ & $\begin{array}{l}\text { CommonGround } \\
\text { WB: SDM program } \\
\text { with peer content } \\
\text { and peer support, } \\
\text { used to create }\end{array}$ & $\begin{array}{l}n=12 \\
\text { SMI: Unspecified \% } \\
\text { schizophrenia/psychotic } \\
\text { disorders; } 58 \% \text { male; } \\
\text { mean age } 45 \text { years }\end{array}$ & $\begin{array}{l}n=155 \mathrm{CM}, 3 \\
\text { prescribers, } 3 \text { nurses, } \\
2 \mathrm{PW}, 2 \text { supervisors }\end{array}$ \\
\hline $\begin{array}{l}\text { Bonfils, } \\
\text { Dreison } \\
{[48]}\end{array}$ & $\begin{array}{l}\text { Mixed-methods: worker } \\
1: 1 \mathrm{IV} \text { at end of } \\
\text { intervention use, SU } \\
\text { usage data, fidelity } \\
\text { reports } 2 / 4\end{array}$ & $\begin{array}{l}\text { One urban } \\
\text { community MH } \\
\text { centre, Indiana, } \\
\text { USA 2013-2015 }\end{array}$ & $\begin{array}{l}\text { health report. } \\
\text { Report viewed by } \\
\text { prescriber and used } \\
\text { in appointments to } \\
\text { make shared decisions, } \\
\text { final plan shared with } \\
\text { treating team. }\end{array}$ & $\begin{array}{l}n=167 \\
\text { SMl: } 67 \% \text { schizophrenia } \\
\text { diagnosis; } 57 \% \text { male; } \\
\text { age not disclosed }\end{array}$ & $\begin{array}{l}n=12 \\
\text { supervisors, PWs, } \\
\text { psychiatrists, managers }\end{array}$ \\
\hline $\begin{array}{l}\text { Korsbek and } \\
\text { Tonder [49] }\end{array}$ & $\begin{array}{l}\text { Qualitative description, } \\
\text { single group pilot study: } \\
\text { worker FGs, SU 1:1 } \\
\text { IVs held after using } \\
\text { intervention } 4 \text { months } \\
\text { 1/4 }\end{array}$ & $\begin{array}{l}\text { Hospital, community } \\
\text { MH, psychosis } \\
\text { treatment centre, } \\
\text { Denmark, Year } \\
\text { not stated }\end{array}$ & $\begin{array}{l}\text { Momentum } \\
\text { MDB and WB: SDM } \\
\text { app, with peer } \\
\text { support. SU used to } \\
\text { prepare for meeting } \\
\text { and could authorize } \\
\text { worker access. } \\
\text { Workers logged in } \\
\text { to treatment site to } \\
\text { view shared } \\
\text { preparations. }\end{array}$ & $\begin{array}{l}n=7 \text { of } 78 \text { participants } \\
\text { with SMI, including } \\
\text { schizophrenia, affective } \\
\text { disorders; gender and } \\
\text { age not disclosed }\end{array}$ & $\begin{array}{l}n=19 \\
12 \text { workers: nurses, } \\
\text { OT, psychologist, SW; } \\
7 \text { doctors }\end{array}$ \\
\hline $\begin{array}{l}\text { Blankers, van } \\
\text { Emmerik [50] }\end{array}$ & $\begin{array}{l}\text { Quantitative non- } \\
\text { randomized, two } \\
\text { group pilot study: } \\
\text { blended FACT (with } \\
\text { SM focus) and } \\
\text { conventional FACT } \\
\text { Standardized SU }\end{array}$ & $\begin{array}{l}\text { SMI community } \\
\text { treatment centre, } \\
\text { Netherlands, } \\
\text { 2012-2013 }\end{array}$ & $\begin{array}{l}\text { Blended flexible } \\
\text { assertive community } \\
\text { treatment (Blended FACT) } \\
\text { WB: Information and } \\
\text { education portal, } \\
\text { appointment scheduling } \\
\text { and a peer forum. Skype }\end{array}$ & $\begin{array}{l}n=47 \\
\text { SMI including } 40 \% \\
\text { schizoaffective disorder } \\
\text { or schizophrenia; } 47 \% \\
\text { male; mean age } 46 \text { years }\end{array}$ & $\begin{array}{l}n=\text { undisclosed } \\
\text { psychiatric nurses }\end{array}$ \\
\hline
\end{tabular}


Table 2 Study characteristics: Interventions used with usual mental health worker (Continued)

\begin{tabular}{|c|c|c|c|c|c|}
\hline Study & Design/MMAT Rating & Setting/Country/Year & Intervention & Service users/ diagnosis & Workers/ profession \\
\hline & $\begin{array}{l}\text { questionnaires at } \\
\text { baseline and } 3 \\
\text { months } \\
2 / 4\end{array}$ & & $\begin{array}{l}\text { contact with nurses. } \\
\text { Computer, Internet } \\
\text { and webcam provided } \\
\text { to SU. }\end{array}$ & & \\
\hline $\begin{array}{l}\text { Gammon, } \\
\text { Strand [51] }\end{array}$ & $\begin{array}{l}\text { Mixed-methods: single } \\
\text { group (two sites) } \\
\text { exploratory study. SU } \\
\text { questionnaires BL; usage } \\
\text { data; SU and worker FGs } \\
\text { after using intervention } 3 \\
\text { months; SU discussion } \\
\text { groups and forum posts; } \\
\text { documents } 2 / 4\end{array}$ & $\begin{array}{l}\text { Multiple health } \\
\text { services, } 1 \text { urban, and } \\
1 \text { rural community, } \\
\text { Norway, 2015-2016 }\end{array}$ & $\begin{array}{l}\text { ReConnect } \\
\text { WB: recovery-focused } \\
\text { portal with resources } \\
\text { and information, } \\
\text { messaging with } \\
\text { providers, peer } \\
\text { support forum; } \\
\text { workers had partial } \\
\text { portal access. }\end{array}$ & $\begin{array}{l}n=29 \\
\text { Receiving MH services at } \\
\text { least } 6 \text { months; including } \\
10 \% \text { schizophrenia-related } \\
\text { diagnosis; } 14 \% \text { male; } \\
\text { mean age } 44 \text { years }\end{array}$ & $\begin{array}{l}n=27 \\
\text { including } 11 \text { nurses, } \\
5 \text { SW, } 3 \text { physicians }\end{array}$ \\
\hline $\begin{array}{l}\text { Strand, } \\
\text { Gammon } \\
{[52]}\end{array}$ & $\begin{array}{l}\text { Qualitative description: } \\
\text { SU and worker FGs early } \\
\text { stage; } 1: 1 \text { IVs and } 1 \text { dyad } \\
\text { IV late stage } 4 / 4\end{array}$ & & & $n=14$ (subset of above) & $n=17$ (subset of above) \\
\hline
\end{tabular}

$B L$ baseline, $C M$ case manager, FG focus group, IT information technology, $I V$ interview, MDB mobile-device based, $M H$ mental health, OT occupational therapist, $P W$ peer worker, RCT randomized controlled trial, SDM shared decision making, SM self-management, SMI severe mental illness, SU service user, SW social worker, WB web-based ${ }^{\mathrm{a}}$ MMAT rating for qualitative study only as no quantitative results reported

study. Table 4 and Additional file 1 provide further details to support the following narrative account.

\section{Interventions used with usual mental health workers}

Intervention goals The primary goal of the seven interventions was to facilitate service user self-management [42, 44, 45, 50]; promote shared decision making [49]; and to support personal recovery via increasing service user involvement in care and collaboration with providers [47, 51]. Authors referenced concepts including self-efficacy [42], self-determination [47], and recoveryoriented practice $[49,51]$, with a focus on the need for interventions that facilitate service users' active role in managing their health.

Intervention tools Two tools were present in 6/7 interventions: a communication channel with workers and information or tools to support daily living. Communication occurred digitally through the Internet using email, text or video chat $[44,45,50,51]$. Sharing information to support daily living was facilitated by workers being able to view service user generated digital content, such as their preparation for meetings [49], mood monitoring [45], and personal goal statements (e.g.[47, 51]). In Miele.net [42, 43] and ReConnect [51, 52], workers and service users could also access and discuss online information or tools together in face-to-face meetings. Service user communication with peers through a forum or text messaging was also possible in four interventions $[42,44,50,51]$, while CommonGround $[47,48]$ and Momentum [49] facilitated direct contact with a peer specialist.
Intervention use The interventions enabled flexible Internet-based communication between service users and workers, often associated with preparing for their meetings (e.g. [42, 47-50]). Service users could also use information websites, online health records and other online tools when they chose (e.g. [42, 44, 46, 51]). Uptake of the interventions was varied. For example, in ReConnect [51] workers' website use ranged from never to almost daily. In another example of varied use, only $65 \%$ of service users completed a web-based health report at least once over a 20-month period in the CommonGround (Indiana) study [48]. Intervention use also diminished over time in the longer duration studies. Site visits to the PCR website initially dropped and then stabilized in months 5 and 6 [44]. In the MHEN study, 93\% of service users were using their smartphone after 12 months, but only $45 \%$ were still accessing their webbased health record [46].

Factors that contributed to low use included complex logging-in procedures (6/7 interventions), the intervention not integrating with other Internet-based systems in the service (6/7 interventions), and workers believing that service users were not suited to using the intervention ( $4 / 7$ interventions) (Table 4). Some service users were deemed unsuitable by some workers on the grounds of being too sick [42], too low functioning [49] or likely to be intimidated by using computers [48]. In contrast, intervention use was facilitated if the pre-existing relationship between a worker and service user was positive $[47,49,51]$, if workers encouraged and supported service users with the intervention [49], and if expectations about how they would both engage with the intervention were clarified $[44,52]$. Worker engagement with the intervention was "considered essential for successful use by some consumers" [52]. 
Table 3 Study characteristics: Interventions used with worker employed in research

\begin{tabular}{|c|c|c|c|c|c|}
\hline Study & Design/MMAT Rating & $\begin{array}{l}\text { Setting/Country/ } \\
\text { Year }\end{array}$ & Intervention & Service users/ diagnosis & $\begin{array}{l}\text { Workers/ } \\
\text { profession }\end{array}$ \\
\hline $\begin{array}{l}\text { Baumel, } \\
\text { Correll (53) }\end{array}$ & $\begin{array}{l}\text { Quantitative, single group, } \\
\text { descriptive study: contact } \\
\text { logs and SU survey after } \\
6 \text { months of use } 1 / 4\end{array}$ & $\begin{array}{l}\text { Ten MH services, } \\
\text { USA, 2013-2014 }\end{array}$ & $\begin{array}{l}\text { Health Technology } \\
\text { Program (HTP) WB and } \\
\text { MDB: smartphone illness } \\
\text { SM app, website with } \\
\text { daily support and } \\
\text { education resources. } \\
\text { Smartphone and laptop } \\
\text { provided to SU. Workers } \\
\text { support use, view website } \\
\text { data and respond to } \\
\text { messages. }\end{array}$ & $\begin{array}{l}n=200 \\
\text { schizophrenia, } \\
\text { schizoaffective disorder, } \\
\text { psychotic disorder } \\
\text { currently or recently } \\
\text { in hospital; } \\
59 \% \text { male; mean } \\
\text { age } 34 \text { years }\end{array}$ & $\begin{array}{l}n=\text { undisclosed } \\
\text { Health } \\
\text { technology coach } \\
\text { (research role): } \\
\text { trained CM }\end{array}$ \\
\hline $\begin{array}{l}\text { Thomas, } \\
\text { Farhall (54) }\end{array}$ & $\begin{array}{l}\text { Quantitative, feasibility } \\
\text { pilot, single group study } \\
\text { after } 3 \text { months use: SU } \\
\text { questionnaires, usage } \\
\text { data, and post intervention } \\
1: 1 \text { IV used as illustrative } \\
\text { quotes } 4 / 4\end{array}$ & $\begin{array}{l}\text { Community MH } \\
\text { service, Australia, } \\
2015\end{array}$ & $\begin{array}{l}\text { Self-Management and } \\
\text { Recovery Technology } \\
\text { (SMART) } \\
\text { WB SM and recovery- } \\
\text { focused website. } \\
\text { Tablet device provided } \\
\text { to worker to use } \\
\text { website with SU in } \\
8 \text { sessions. }\end{array}$ & $\begin{array}{l}n=10 \\
\text { psychotic disorder; } 90 \% \\
\text { male; mean age } 42 \text { years }\end{array}$ & $\begin{array}{l}n=2 \\
\text { MH worker } \\
\text { (research role) }\end{array}$ \\
\hline $\begin{array}{l}\text { Schlosser, } \\
\text { Campellone } \\
\text { (55) }\end{array}$ & $\begin{array}{l}\text { Quantitative, single } \\
\text { group feasibility study } \\
\text { in intervention design } \\
\text { phase and prior to RCT: } \\
\text { SU satisfaction and usage } \\
\text { data, after } 3 \text { months use. } \\
\text { 1:1 IV used as illustrative } \\
\text { quotes } 4 / 4\end{array}$ & $\begin{array}{l}\text { Early psychosis clinic } \\
\text { and community } \\
\text { treatment centres, } \\
\text { USA, year not stated }\end{array}$ & $\begin{array}{l}\text { Personalized Real-Time } \\
\text { Intervention for Motivation } \\
\text { Enhancement (PRIME) } \\
\text { MDB and WB: smartphone } \\
\text { app for SU to select and } \\
\text { monitor goals, communicate } \\
\text { with peers, and worker. } \\
\text { Profile viewed by worker } \\
\text { on website. } \\
\text { Smart phone provided } \\
\text { to SU. }\end{array}$ & $\begin{array}{l}n=20 \\
\text { recent onset } \\
\text { schizophrenia (10 used } \\
\text { PRIME version 1, } 10 \text { used } \\
\text { PRIME version 2); } 85 \% \\
\text { male, mean age } 23 \text { years }\end{array}$ & $\begin{array}{l}n=6 \\
\text { Motivation } \\
\text { coaches } \\
\text { (research role): } \\
\text { Masters-level } \\
\text { clinicians }\end{array}$ \\
\hline $\begin{array}{l}\text { Fortuna, } \\
\text { Dimilia (56) }\end{array}$ & $\begin{array}{l}\text { Quantitative, pilot } \\
\text { feasibility study, single } \\
\text { group: SU questionnaires } \\
\text { at BL, } 1 \text { and } 3 \text { months; } \\
\text { fidelity assessment; usage } \\
\text { data 3/4 }\end{array}$ & $\begin{array}{l}\text { Community clinical } \\
\text { teams, USA, year not } \\
\text { stated }\end{array}$ & $\begin{array}{l}\text { PeerTECH } \\
\text { MDB and WB: smartphone } \\
\text { SM app, WB eModules } \\
\text { delivered in sessions with } \\
\text { PW, text messaging with } \\
\text { PW. Smartphone provided } \\
\text { to SU. }\end{array}$ & $\begin{array}{l}n=8 \\
\text { Older adults, } \\
\text { SMl and co-morbid chronic med- } \\
\text { ical conditions: } 25 \% \text { schizophrenia } \\
\text { diagnosis; } 12.5 \% \text { male; mean age } \\
68 \text { years }\end{array}$ & $\begin{array}{l}n=3 \\
\text { Certified peer } \\
\text { specialists } \\
\text { (research role) }\end{array}$ \\
\hline
\end{tabular}

$B L$ baseline, $C M$ case manager, $I V$ interview, $M D B$ mobile-device based, $M H$ mental health, $P W$ peer worker, $R C T$ randomized controlled trial, $S M$ self-management, $S M I$ severe mental illness, $S U$ service user, WB web-based

\section{Interventions used with research workers}

Intervention goals Two of the four Internet-based interventions used with mental health workers employed for a research project aimed to support self-management, one with a focus on relapse prevention for people recently discharged from hospital care for schizophrenia [53] and one addressing self-management of mental and physical health in older people [56] (Table 4). SMART aimed to promote personal recovery and self-management [54]. PRIME aimed to improve motivation and functioning in people with recent onset schizophrenia and was included as the approach incorporated self-determined goals and "a collaborative, reinforcing and strengths-based approach" consistent with personal recovery [55].

Intervention tools All were multi-component smartphone-accessible interventions. Smartphones were provided to service users if needed in three studies [53, 55, 56], while SMART workers used a tablet computer in their meetings with service users [54]. Tools embedded in the interventions included educational modules (3/4 interventions); peer communication tools $(3 / 4)$; and peer videos $(2 / 4)$.

Intervention use Adherence to interventions appeared to be overall high. The research worker's role included having face-to-face meetings with participants at the setup stage only [55], regularly over three months [54,56], or for six months [53]. This prescribed face-to-face contact contrasted with the interventions used with usual mental health workers, where it was less common for workers and service users to use the interventions together faceto-face (Table 4). All interventions excepting SMART also enabled text-based chat or messaging between workers and individual participants. Usage data indicated that all four interventions were feasible and acceptable. 


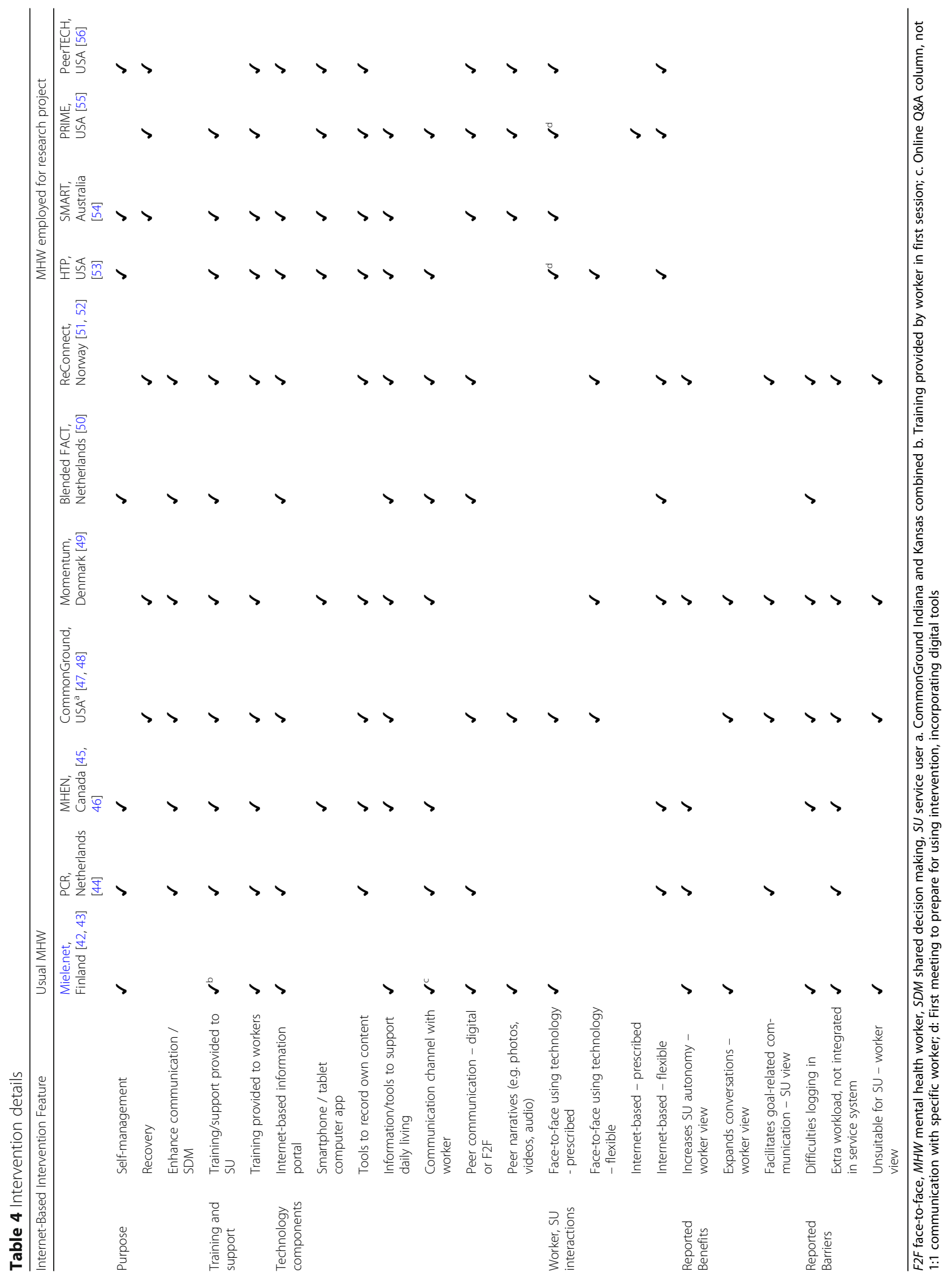


Influences of jointly using an Internet-based intervention on practice

\section{Influences on interactions between service users and} workers

Key findings about the influence of Internet-based interventions on interactions between service users and their usual workers were synthesized into two preliminary themes: "working together" and "feelings of mistrust and not being appreciated". Related findings from the studies with research workers are included in these themes, where relevant.

Working together Collaboratively using an Internetbased intervention had the potential to create a "sense of working together" [43] for service users and their usual mental health workers. Working together arose when the Internet tools and communication channels opened conversations between service users and workers [42, 47-49, 52], as indicated by a nurse using Mieli.Net:

"There have been good conversations in education sessions, so I consider web pages to be quite helpful in nursing." ([42], p.151).

These conversations were described by workers as "productive" [48], "wide-ranging" [42] and about what was important to service users [52]. Service users reported that access to online tools, information and messaging enabled them to write down their ideas and to ask questions when they wanted rather than waiting for their next appointment $[44,52]$. They appreciated their workers being more available [45] and shared more information:

"They wouldn't get as much information out of me (prior to CommonGround)...once I tell the computer what my situation is, and they discuss it with me... that has helped" ([47], p.270).

Working together was further enhanced when service users reflected on and communicated their goals through the intervention [44, 45, 47, 51]. Primarily, meaningful service user goals became visible, injecting a specific direction to working together. Workers perceived that service users could "set an agenda of their own and structure what was important" [49]. Workers could then support personal goal striving, as indicated by this worker in ReConnect:

"The goal module has really helped. When he/she says, "I wish I'd do more of this," then I can put pressure on. When it's written down in there as a concrete goal, then it kind of lights up a fire of sorts.” ([51], p.8).
Service users perceived that they were more in control of decision making [44, 45, 47, 52], as discussions gained new starting points, a clear focus and incorporated their resources and goals. In the MHEN study, the authors asserted that:

"Since adopting this technology, many clients expressed feelings of greater control in their health management and in their life" ([45], p.4).

Pre-existing working relationships influenced whether working together occurred $[49,51]$. For example, existing trusting relationships overcame service users' initial fears about using the intervention [49]. In ReConnect, the researchers considered that pre-existing poor working relationships were exposed when workers did not use the intervention with service users [51]. Engagement with the intervention, required to facilitate working together, was supported when workers [42], service users [46] or both [49], perceived the intervention to be easy to use.

Consistent with the above analysis, participant quotes from the SMART study suggested that interesting discussions were elicited and guided through using a website with a worker employed for a research project. One SMART participant noted that discussions were less intimidating and more directed towards "what you had to say and what you thought about situations". Another SMART participant stated:

[Without the website] "we wouldn't have had nearly as much to talk about. And then I would have been more stuck for words I think. I wouldn't have been able to talk about all the issues that we had discussed about the website" ([54], p.8).

In the PRIME study involving research workers as coaches [55], it was noted when coaches sent frequent, brief, and casual messages to participants, service user responses changed from a ratio of 12:1 (coach initiated interactions to service user response), to a ratio of $3: 1$. In summary, these studies demonstrated that using the intervention with a research worker supported regular communication between the user and worker on a range of topics. Factors that supported this outcome were hypothesised to include the opportunity for daily messaging $[55,56]$ and workers providing training and technical assistance to service users [53].

Feelings of mistrust and not being appreciated In contrast, relationships could be negatively affected by "feelings of mistrust and not being appreciated" [52], that arose when expectations about getting started with the intervention or the frequency of each party's engagement 
were unreciprocated or mismatched [44, 45, 48, 51]. This was particularly so for service users in ReConnect when their workers failed to actively participate in the Internet-based intervention:

"Why did [provider] agree to work with me through this tool if she never expected to do it? She should have just said no. You get so disappointed" ([51], p.9).

Workers could also experience frustration if they perceived that a service user was hard to engage in the intervention, as described by a nurse in Miele.net:

\section{"It's hard work on busy days with an uninterested patient" ([42], p.151).}

Influences on workers' decisions to actively use the intervention included some workers being concerned not to burden service users [51], or them assuming service users were too sick [42], or too poorly functioning [49] to use the intervention. Workers also forgot to look for online messages, or often had difficulty fitting the intervention into their workload and existing systems [42, 44, 45, 52]. A worker in CommonGround Indiana noted:

"I feel like they (workers) have so much they have to do already that trying to say, "hey, make sure you get people in for CommonGround" would just feel overwhelming to them" ([48], p.4).

Some ReConnect workers described waiting for service users to initiate use of the intervention, as they saw this as being consistent with their clients taking more control [52]. However, some service users were uncertain what they needed [52] or did not want to disturb their worker [49, 52]. In Momentum it was noted that service user initiation could be stalled if there was an imbalance of power in the relationship:

"a consumer explained that she did not dare to share it (her treatment preparation), as some of her considerations might be irrelevant for the staff" ([49], p.171).

In addition to the above barriers, workers in ReConnect could find it difficult to interact with service users through the Internet due to worrying that their text messages might be misinterpreted or feeling overwhelmed by long and frequent messages from service users [52].

\section{Influences on recovery-oriented practice}

Results for this section consider all 11 interventions. Recovery-oriented practices as outlined by Slade et al.
[39] appeared to be elicited when Internet-based interventions were used by service users and workers in mental health services. Firstly, service users' values and treatment preferences were identified and integrated into work with mental health workers. This was demonstrated through workers noting that using the intervention enabled service users to set the agenda for appointments $[49,52]$, and gave them more control of treatment decisions [44, 45, 47, 49, 52]. Characteristics of the interventions including information portals (e.g. $[42,44])$ and interactive tools ([e.g. [52, 54]) supported service users to communicate about topics that mattered to them. Secondly, functions included in several interventions supported user-generated goal striving, for example, the goals and activities in ReConnect [51]; the power statement in CommonGround [47, 48]; and the daily challenge in PRIME [55]. While the practice of assessing and amplifying service user strengths was less explicitly evident, two studies identified that using the intervention helped workers to be more aware of service users' resources [42, 51], and exercises related to identifying strengths and resources were included in ReConnect [51] and SMART [54]. Recovery-oriented practices were less evident when the intervention was not well integrated into practice or not used by both parties.

\section{Discussion}

\section{Principal findings}

This review substantiates that Internet-based interventions designed for joint use by people experiencing SMIs and mental health workers, with a focus on self-management, recovery and shared decision-making, are increasingly available in mental health services. Nine of the 15 included studies $(60 \%)$ were published since 2016 and only three of the 11 identified interventions were included in a previous related review [24], demonstrating the growing pace at which jointly used Internet-based interventions are developing. These facilitated service users' active contributions towards their health and care planning and increased their opportunities to communicate with workers and peers about what was important to them. Furthermore, when well-integrated into practice with strong worker engagement, these Internet-based interventions demonstrated potential to positively influence interactions between service users and workers and to promote recovery-oriented practice. They increased focus on service users' goals and treatment preferences. Although the quantity and quality of evidence available is modest, it suggests that joint use of Internet-based interventions between service users and workers can bring a person-centred and goal-oriented focus to discussions. However, the review also establishes that Internet-based interventions can negatively influence interactions between service users and workers and suggests 
that they will not necessarily change practice if the preexisting working relationship is poor.

\section{Key features of Internet-based interventions that supported their joint use}

Recommendations that Internet-based and mobile interventions need to be flexible and developed with user input to cater for a range of users experiencing SMI [17] were evident across the interventions in this review. Service-user and worker consultation was common in intervention design, reflecting a user-centred approach that is essential to creating engaging and easy to use interventions [17] and supports innovation success in mental health services [57, 58]. Training and support were also frequently offered to service users and workers in the 11 interventions, factors that are conducive to success [57]. However, there is scope for greater participation of service users in research related to these interventions, as has been possible in other areas of recoveryrelated research $[59,60]$.

Mobile technologies, specifically smartphone apps, may be particularly important to include, as people experiencing SMI feel comfortable using their own devices; apps can support remembering, initiating and maintaining strategies [21]; and smartphone interventions are quicker to use $[18,20]$. This was demonstrated by service users in the MHEN study preferring to use smartphone applications for appointment and medication reminders rather than their web-based health record [46]. The interventions with web-based portals (e.g. $[42,51])$ were also valuable, as these provided service users and workers access to a wide range of information and tools. In several interventions, providing smartphones $[45,55,56]$ or computers to service users [50,53], and tablets to workers [46, 54], supported intervention engagement. Although rates of mobile phone ownership are high and increasing among people experiencing psychosis [10,11], a small group of older people continue to experience digital exclusion [21,61] and may benefit from devices being provided.

It is notable that $9 / 11$ interventions included contact with peers, as digital communication in six interventions and as face-to-face support in five. Opportunities for online communication with peers has potential to increase service users' hope $[62,63]$. Further research investigating the role of peers in Internet-based interventions used with workers is warranted, as hope has previously been identified as a missing theme in Internet-based selfmanagement interventions [19].

\section{Influence of jointly using Internet-based interventions on interactions}

Preliminary evidence suggests that Internet-based interventions used by service users and workers can create a positive sense of working together. Digital tools for communication and shared decision-making that facilitated service users to explore, record and discuss their health, goals, treatment preferences and care plans (e.g. [48, 51, 54]) appeared to contribute to this outcome. When integrated into the working relationship, using Internetbased interventions could lead to more productive discussions (e.g. [42, 47, 49, 51, 54]) and service users gaining more control over health-related goals and decisions (e.g. [44, 45]). In comparison, not working in partnership may be indicated when there is no meeting agenda and agreement about the primary purpose of psychiatric visits is low [64]. Likewise, care plans can be perceived as being only relevant to professionals and inconsequential to everyday life when service users are not partners in their development [65]. While intervention component use could diminish over time (e.g. [46]), the ongoing benefits of accessible communication (e.g. $[44,45,55])$ and a stronger link to service user goals in meetings (e.g. [48])] could support continued use.

Working relationships were not always strengthened when service users and workers used Internet-based interventions. Mismatched expectations about initial and subsequent use could result in frustration and disappointment, negatively influencing the trust that characterizes therapeutic relationships between service users who experience SMI and mental health workers [66]. For example, trust may have been broken if a service user perceived that the worker lacked commitment, as demonstrated by them not investing enough time to attend to the Internet-based modules or messages that they posted. Additionally, when workers made decisions about which clients were suited to using the intervention, this suggested a paternalistic approach, more aligned to clinically defined than personally defined recovery [67].

Our review indicates that mental health workers' engagement in Internet-based interventions is an important factor in engaging service users experiencing SMI. Previous research has identified that workers have varying views about using Internet-based resources with service users, which include workers anticipating taking more, or less control of the resources [68]. This suggests that expectations about using Internet-based interventions need to be clarified between workers and service users. Agreements could be made about who will initiate use, the frequency of use and how the intervention will be used in face-to-face meetings, as well as online. As also identified by Strand, Gammon [24], workers' engagement was affected when Internet-based interventions duplicated other processes, were difficult to fit into work flows or overwhelmed workers. Fitting Internetbased interventions into work flows is a common challenge in health settings [69]. This finding supports the 
call for close consideration of organizational factors in addition to stakeholder consultation during the initial phase of creating technology-enabled services [58] in mental health.

\section{Opportunities to support recovery-oriented practice through jointly using Internet-based interventions}

Using Internet-based interventions offers potential to embed aspects of recovery-oriented practice into working relationships. Identifying this potential is important, because the nature of relationships matters in recoveryoriented practice $[3,4,70]$. Internet-based interventions demonstrated potential to elicit service user's values and treatment preferences and support their goal striving (e.g. [47, 55]), two working practices targeted for recovery-oriented practice [39]. This is consistent with service users reporting that it is helpful for their recovery when services support them to achieve self-identified life goals [71]. Sharing this information with workers set the agenda for meetings and increased service user involvement $[49,52]$, promoting a partnership-style of relationship, as supports recovery [3]. The next generation of Internet-based interventions could include more resources that focus on service-user strengths [72], to further support recovery-oriented practice.

\section{Future research}

Several research design issues are evident from this scoping review. Firstly, rigorous quantitative studies are still needed to demonstrate intervention effectiveness, as most evidence to date is exploratory and descriptive. Another important issue is the need for Internet-based interventions to become sustainable within mental health services [58]. Arguably, sustainability will be easier if usual mental health workers are involved in future intervention studies, rather than research workers as occurred in four of the interventions included in this review. Researchers completing a detailed eHealth checklist [73], including specifying the theoretical framework when reporting interventions will support greater intervention transparency and more specific detail than can be reported using the TIDieR checklist [38]. The nature and quality of support influences helping relationships [22, 23, 70, 74], so understanding more about the type of support needed by service users when using Internet interventions with their worker is warranted in future research. Dyad interviews could facilitate exploring the shared experience and meaning of using Internet-based resources together [75] and build knowledge about how dyads negotiate expectations and the worker actions that support intervention use. Finally, as this field of research matures, international research collaborations would be beneficial to increase access to Internet-based interventions in more mental health services across the world. Collaborations could also reduce the inherent risk of rapid obsolescence in technologyenabled services [58] if many research teams with timelimited funding continue to develop new Internetinterventions.

\section{Strengths and Limitations}

A comprehensive and iterative search phase was a strength of this review. However, strict inclusion and exclusion criteria meant that several Internet-based interventions for people experiencing SMI designed for use in mental health services were excluded. For instance, an intervention like HORYZON [30] included elements that could be used by service users and workers together, although this type of use was not reported in the published research. Including studies where a research worker, rather than a usual mental health worker, engaged with a service user could reduce applicability to usual working relationships. These studies were considered separately when exploring the impact of using Internet-based interventions on service-user and worker interactions, to limit this risk. The depth of qualitative data was variable in the included studies, with only one study focusing specifically on working relationships [52]. Further high-quality qualitative research is needed to expand the preliminary findings regarding working together that were synthesized from existing mixed methods and descriptive qualitative research. Finally, consultation with stakeholders as recommended in revisions to scoping review methodology $[26,27]$ was not included, primarily because the field of research is young, and timely and broad consultation was not feasible. Assuming the pace of development continues, this will be an important factor to address in future reviews.

\section{Conclusions}

Rapid growth in Internet-based interventions for people experiencing SMI has recently translated into more readily available Internet-based interventions focused on self-management and recovery for service users and mental health workers to use together in mental health services. The findings from this scoping review indicate that when these Internet-based interventions are wellintegrated into practice, they can support service users' involvement in their care, promote a sense of working in partnership, and support recovery-oriented practices. However, mistrust in service user-provider working relationships can also develop if expectations about using the intervention are not clarified, and if the interventions are not embedded into usual mental health service systems. The challenge for future practitioners and researchers alike is to attend to the human support component of Internet-based interventions with the same level of attention that has been given to developing and implementing their technological components. 


\section{Additional file}

Additional file 1: Jointly used Internet-based interventions - TIDieR intervention details and study findings. (DOCX $80 \mathrm{~kb}$ )

\section{Abbreviations}

CINAHL: Cumulative index to nursing and allied health literature: FACT: Flexible assertive community treatment; HTP: Health technology program; MHEN: Mental health engagement network; MMAT: mixed methods appraisal tool; PCR: Personal control in rehabilitation; PRIME: Personalized real-time intervention for motivation; SDM: shared decision making; SMART: Self-management and recovery technology; SMI: Severe mental illness; TIDieR: Template for intervention description and replication

\section{Acknowledgements}

We gratefully acknowledge La Trobe University librarians for their expert review and advice on our search strategy.

\section{Authors' contributions}

AW, JF, EF and NT conceived the review question and designed this scoping review. AW conducted the search, which was reviewed with JF. AW and JF selected studies and consulted with NT on refinements to the inclusion and exclusion criteria. AW charted the data. AW, JF and EF collated and summarized the results, which were discussed by AW, JF, EF and NT. AW drafted the manuscript, which was critically reviewed and revised by JF, EF and NT. All authors read and approved the final manuscript.

\section{Author's Information}

All authors are affiliated with the Self-Management And Recovery Technology (SMART) research project, which is led by NT. The SMART research program was funded by the State Government of Victoria, Department of Health, Mental IIIness Research Fund (MIRF33). This scoping review was undertaken as part of the first author's PhD studies, supported by an Australian Government Research Training Program Scholarship.

\section{Funding}

Not applicable

\section{Availability of data and materials}

Not applicable

\section{Ethics approval and consent to participate}

Not applicable

\section{Consent for publication}

Not applicable

\section{Competing interests}

The authors declare that they have no competing interests

\section{Author details}

'Department of Occupational Therapy, Social Work and Social Policy, La Trobe University, Melbourne, Victoria, Australia. ${ }^{2}$ Department of Health Professions, Swinburne University of Technology, Hawthorn, Victoria, Australia. ${ }^{3}$ Department of Psychology and Counselling, La Trobe University, Melbourne, Victoria, Australia. ${ }^{4}$ NorthWestern Mental Health, Melbourne Health, Melbourne, Melbourne, Victoria, Australia. ${ }^{5}$ Department of Occupational Therapy, Monash University, Frankston, Victoria, Australia. ${ }^{6}$ Living with Disability Research Centre, La Trobe University, Melbourne, Victoria, Australia. ${ }^{7}$ Centre for Mental Health, Swinburne University of Technology, Hawthorn, Victoria, Australia. ${ }^{8}$ Monash Alfred Psychiatry Research Centre, Melbourne, Victoria, Australia.
Received: 31 July 2018 Accepted: 20 May 2019

Published online: 20 June 2019

\section{References}

1. Morgan VA, Waterreus A, Jablensky A, Mackinnon A, McGrath JJ, Carr V, Galletly C. People living with psychotic illness in 2010: the second Australian national survey of psychosis. Aust N Z J Psychiatry. 2012;46(8):735-52.

2. Sterling EW, Silke A, Tucker S, Fricks L, Druss BG. Integrating wellness, recovery, and self-management for mental health consumers. Community Ment Health J. 2010;46(2):130-8.

3. Chester P, Ehrlich C, Warburton L, Baker D, Kendall E, Crompton D. What is the work of recovery oriented practice? A systematic literature review. Int J Ment Health Nurs. 2016:25(4):270-85.

4. Slade M, Longden E. Empirical evidence about recovery and mental health. BMC Psychiatry. 2015;15:285.

5. Le Boutillier C, Leamy M, Bird VJ, Davidson L, Williams J, Slade M. What does recovery mean in practice? A qualitative analysis of international recoveryoriented practice guidance. Psychiatr Serv. 2011;62:1470-6.

6. Leamy M, Bird V, Le Boutillier C, Williams J, Slade M. Conceptual framework for personal recovery in mental health: systematic review and narrative synthesis. Br J Psychiatry. 2011;199:445-52.

7. Andresen R, Oades L, Caputi P. The experience of recovery from schizophrenia: towards an empirically validated stage model. Aust N Z J Psychiatry. 2003:37(5):586-94.

8. Ben-Zeev D, Drake RE, Corrigan PW, Rotondi AJ, Nilsen W, Depp C. Using contemporary technologies in the assessment and treatment of serious mental illness. Am J Psychiatr Rehabil. 2012;15:357-76.

9. Ben-Zeev D, Davis KE, Kaiser S, Krzsos I, Drake RE. Mobile technologies among people with serious mental illness: opportunities for future services. Adm Policy Ment Health. 2013;40(4):340-3.

10. Firth J, Cotter J, Torous J, Bucci S, Firth JA, Yung AR. Mobile phone ownership and endorsement of "mHealth" among people with psychosis: a meta-analysis of cross-sectional studies. Schizophr Bull. 2015:42(2):448-55.

11. Thomas N, Foley F, Lindblom K, Lee S. Are people with severe mental illness ready for online interventions? Access and use of the Internet in Australian mental health service users. Australas Psychiatry. 2017;25(3):257-61.

12. Villani M, Kovess-Masfety $\mathrm{V}$. How do people experiencing schizophrenia spectrum disorders or other psychotic disorders use the Internet to get information on their mental health? Literature review and recommendations. JMIR Ment Health. 2017:4:e1.

13. Gaebel W, Großimlinghaus I, Kerst A, Cohen Y, Hinsche-Böckenholt A, Johnson B, et al. European Psychiatric Association (EPA) guidance on the quality of eMental health interventions in the treatment of psychotic disorders. Eur Arch Psychiatry Clin Neurosci. 2016;266(2):125-37.

14. Álvarez-Jiménez M, Gleeson JF, Bendall S, Lederman R, Wadley G, Killackey E, et al. Internet-based interventions for psychosis. a sneak-peek into the future. Psychiatr Clin. 2012;35(3):735-47.

15. Naslund JA, Marsch LA, McHugo GJ, Bartels SJ. Emerging mHealth and eHealth interventions for serious mental illness: a review of the literature. $J$ Ment Health. 2015:24(5):321-32.

16. Berry N, Lobban F, Emsley R, Bucci S. Acceptability of interventions delivered online and through mobile phones for people who experience severe mental health problems: a systematic review. J Med Internet Res. 2016;18(5):e121.

17. Alvarez-Jimenez M, Alcazar-Corcoles MA, González-Blanch C, Bendall S, McGorry PD, Gleeson JF. Online, social media and mobile technologies for psychosis treatment: a systematic review on novel user-led interventions. Schizophr Res. 2014;156:96-106.

18. Gire N, Farooq S, Naeem F, Duxbury J, McKeown M, Kundi PS, et al. mHealth based interventions for the assessment and treatment of psychotic disorders: a systematic review. mHealth. 2017;3:33.

19. van der Krieke $L$, Wunderink $L$, Emerencia AC, de Jonge $P$, Sytema S. Emental health self-management for psychotic disorders: state of the art and future perspectives. Psychiatr Serv. 2014;65:33-49.

20. Firth J, Torous J. Smartphone apps for schizophrenia: a systematic review. JMIR mHealth uHealth. 2015;3(4):e102.

21. O'Hanlon P, Aref-Adib G, Fonseca A, Lloyd-Evans B, Osborn D, Johnson S. Tomorrow's world: current developments in the therapeutic use of technology for psychosis. BJPsych Adv. 2016;22(5):301-10.

22. Davidson L, Rowe M, Tondora J, O'Connell MJ, Lawless MS. A practical guide to recovery-oriented practice: tools for transforming mental health care: Oxford University Press; 2008. 
23. Bird V, Leamy M, Le Boutillier C, Williams J, Slade M. Refocus: promoting recovery in mental health services. 2nd ed. London: Rethink Mental Illness; 2014.

24. Strand M, Gammon D, Ruland CM. Transitions from biomedical to recoveryoriented practices in mental health: a scoping review to explore the role of Internet-based interventions. BMC Health Serv Res. 2017;17:257.

25. Arksey H, O'Malley L. Scoping studies: towards a methodological framework. Int J Soc Res Methodol. 2005;8(1):19-32.

26. Levac D, Colquhoun H, O'Brien KK. Scoping studies: advancing the methodology. Implement Sci. 2010;5(1):69.

27. Colquhoun HL, Levac D, O'Brien KK, Straus S, Tricco AC, Perrier L, et al. Scoping reviews: time for clarity in definition, methods, and reporting. J Clin Epidemiol. 2014;67(12):1291-4.

28. Daudt HM, Van Mossel C, Scott SJ. Enhancing the scoping study methodology: a large, inter-professional team's experience with Arksey and O'Malley's framework. BMC Med Res Methodol. 2013;13(1):48.

29. Atkinson KM, Koenka AC, Sanchez CE, Moshontz H, Cooper H. Reporting standards for literature searches and report inclusion criteria: making research syntheses more transparent and easy to replicate. Res Synth Methods. 2015;6(1):87-95.

30. Alvarez-Jimenez M, Bendall S, Lederman R, Wadley G, Chinnery G, Vargas S, et al. On the HORYZON: moderated online social therapy for long-term recovery in first episode psychosis. Schizophr Res. 2013;143(1):143-9.

31. Priebe S, Kelley L, Omer S, Golden E, Walsh S, Khanom H, et al. The effectiveness of a patient-centred assessment with a solution-focused approach (DIALOG+) for patients with psychosis: a pragmatic clusterrandomised controlled trial in community care. Psychother Psychosom. 2015;84(5):304-13.

32. Woltmann E, Wilkniss E, Teachout A, McHugo GJ, Drake RE. Trial of an electronic decision support system to facilitate shared decision making in community mental health. Psychiatr Serv. 2011;62(1):54-60.

33. Deegan P, Drake R. Shared decision making and medication management in the recovery process. Psychiatr Serv. 2006;57(11):1636-9.

34. Pluye P, Gagnon M, Griffiths F, Johnson-Lafleur J. A scoring system for appraising mixed methods research, and concomitantly appraising qualitative, quantitative and mixed methods primary studies in mixed studies reviews. Int J Nurs Stud. 2009:46(4):529-46.

35. Pluye P, Robert E, Cargo M, Bartlett G, O'Cathain A, Griffiths F, et al. Proposal: a mixed methods appraisal tool for systematic mixed studies reviews. 2011. http://mixedmethodsappraisaltoolpublic.pbworks.com/w/page/24607821/ FrontPage. Accessed 4 Jan 2018.

36. Souto R, Khanassov V, Hong Q, Bush P, Vedel I, Pluye P. Systematic mixed studies reviews: updating results on the reliability and efficiency of the mixed methods appraisal tool. Int J Nurs Stud. 2015;52(1):500-1.

37. Pace R, Pluye P, Bartlett G, Macaulay A, Salsberg J, Jagosh J, et al. Testing the reliability and efficiency of the pilot Mixed Methods Appraisal Tool (MMAT) for systematic mixed studies review. Int J Nurs Stud. 2012;49(1):47-53.

38. Hoffmann TC, Glasziou PP, Boutron I, Milne R, Perera R, Moher D, et al. Better reporting of interventions: template for intervention description and replication (TIDieR) checklist and guide. Br Med J. 2014;348:91687.

39. Slade M, Bird V, Le Boutillier C, Farkas M, Grey B, Larsen J, et al. Development of the REFOCUS intervention to increase mental health team support for personal recovery. Br J Psychiatry. 2015;207(6):544.

40. Dixon-Woods M, Agarwal S, Jones D, Young B, Sutton A. Synthesising qualitative and quantitative evidence: a review of possible methods. J Health Serv Res Policy. 2005;10(1):45-53.

41. Bazeley P, Jackson K. Qualitative data analysis with NVivo. London: Sage Publications Limited; 2013.

42. Anttila M, Koivunen M, Välimäki M. Information technology-based standardized patient education in psychiatric inpatient care. J Adv Nurs. 2008;64(2):147-56

43. Koivunen $M$, Huhtasalo J, Makkonen $P$, Välimäki M, Hätönen H. Nurses' roles in systematic patient education sessions in psychiatric nursing. J Psychiatr Ment Health Nurs. 2012;19(6):546-54.

44. de Leeuw J, van Splunteren P, Boerema I. Personal control in rehabilitation: an Internet platform for patients with schizophrenia and their caregivers. Open J Psychiatr. 2012;2:355-61.

45. Forchuk C, Rudnick A, Hoch J, Donelle L, Campbell R, Osaka W, et al. Mental health engagement network: innovating community-based mental healthcare. J Gen Pract. 2014;2:1.

46. Forchuk C, Donelle L, Ethridge $\mathrm{P}$, Warner L. Client perceptions of the mental health engagement network: a secondary analysis of an intervention using smartphones and desktop devices for individuals experiencing mood or psychotic disorders in Canada. JMIR Ment Health. 2015;2(1):e1.

47. Goscha R, Rapp C. Exploring the experiences of client involvement in medication decisions using a shared decision making model: results of a qualitative study. Community Ment Health J. 2015;51(3):267-74.

48. Bonfils KA, Dreison KC, Luther L, Fukui S, Dempsey AE, Rapp CA, et al. Implementing CommonGround in a community mental health center: lessons in a computerized decision support system. Psychiatr Rehabil J. 2016. https://doi.org/10.1037/prj0000225.

49. Korsbek L, Tonder E. Momentum: a smartphone application to support shared decision making for people using mental health services. Psychiatri Rehabili J. 2016;39:167-72.

50. Blankers $M$, van Emmerik A, Richters B, Dekker J. Blended Internet care for patients with severe mental illnesses: an open label prospective controlled cohort pilot study. Internet Interv. 2016:5:51-5.

51. Gammon D, Strand M, Eng LS, Børøsund E, Varsi C, Ruland C. Shifting practices toward recovery-oriented care through an E-recovery portal in community mental health care: a mixed-methods exploratory study. J Med Internet Res. 2017:19(5):e145.

52. Strand M, Gammon D, Eng LS, Ruland C. Exploring working relationships in mental health care via an E-recovery portal: qualitative study on the experiences of service users and health providers. JMIR Ment Health. 2017;4(4):e54.

53. Baumel A, Correll CU, Hauser M, Brunette M, Rotondi A, Ben-Zeev D, et al. Health technology intervention after hospitalization for schizophrenia: service utilization and user satisfaction. Psychiatr Serv. 2016;67(9):1035-8.

54. Thomas N, Farhall J, Foley F, Leitan ND, Villagonzalo K-A, Ladd E, et al. Promoting personal recovery in people with persisting psychotic disorders: development and pilot study of a novel digital intervention. Front Psychiatry. 2016;7:196.

55. Schlosser D, Campellone T, Kim D, Truong B, Vergani S, Ward C, et al. Feasibility of PRIME: a cognitive neuroscience-informed mobile app intervention to enhance motivated behavior and improve quality of life in recent onset schizophrenia. JMIR Res Protoc. 2016;5(2):e77.

56. Fortuna KL, Dimilia PR, Lohman MC, Bruce ML, Zubritsky CD, Halaby MR, et al. Feasibility, acceptability, and preliminary effectiveness of a peerdelivered and technology supported self-management intervention for older adults with serious mental illness. Psychiatr Q. 2017. https://doi.org/10. 1007/s11126-017-9534-7.

57. Brooks H, Pilgrim D, Rogers A. Innovation in mental health services: what are the key components of success? Implement Sci. 2011;6(1):120.

58. Mohr DC, Lyon AR, Lattie EG, Reddy M, Schueller SM. Accelerating digital mental health research from early design and creation to successful implementation and sustainment. J Med Internet Res. 2017;19(5):e153.

59. Neil ST, Price J, Pitt L, Welford M, Nothard S, Sellwood W, et al. Working together: service users and researchers in psychosis research. Psychosis. 2013;5(3):306-16.

60. Davidson L, Shaw J, Welborn S, Mahon B, Sirota M, Gilbo P, et al. "I don't know how to find my way in the world": contributions of user-led research to transforming mental health practice. Psychiatry. 2010;73(2):101-13.

61. Robotham D, Satkunanathan S, Doughty L, Wykes T. Do we still have a digital divide in mental health? A five-year survey follow-up. J Med Internet Res. 2016;18(11):e309.

62. Naslund JA, Grande SW, Aschbrenner KA, Elwyn G. Naturally occurring peer support through social media: the experiences of individuals with severe mental illness using YouTube. PLoS One. 2014:9(10):e110171.

63. Williams A, Fossey E, Farhall J, Foley F, Thomas N. Recovery after psychosis: qualitative study of service user experiences of lived experience videos on a recovery-oriented website. JMIR Ment Health. 2018;5(2):e37.

64. Bonfils KA, Fukui S, Adams EL, Hedrick HM, Salyers MP. Why are you here again? Concordance between consumers and providers about the primary concern in recurring psychiatric visits. Psychiatry Res. 2014;220(0):541-8.

65. Brooks H, Lovell K, Bee P, Sanders C, Rogers A. Is it time to abandon care planning in mental health services? A qualitative study exploring the views of professionals, service users and carers. Health Expect. 2017. https://doi. org/10.1111/hex.12650.

66. Farrelly $\mathrm{S}$, Lester $\mathrm{H}$. Therapeutic relationships between mental health service users with psychotic disorders and their clinicians: a critical interpretive synthesis. Health Soc Care Community. 2014. https:/doi.org/10.1111/hsc.12090.

67. Le Boutillier C, Chevalier A, Lawrence V, Leamy M, Bird VJ, Macpherson R, et al. Staff understanding of recovery-orientated mental health practice: a systematic review and narrative synthesis. Implement Sci. 2015;10(1):87. 
68. Williams A, Fossey E, Farhall J, Foley F, Thomas N. Going online together: mental health workers' views about integrating e-recovery resources into their practice. Psychiatry. 2018;81(2):116-29.

69. Granja $C$, Janssen $W$, Johansen MA. Factors determining the success and failure of eHealth interventions: systematic review of the literature. J Med Internet Res. 2018;20(5):e10235.

70. Davidson L, Chan KK. Common factors: evidence-based practice and recovery. Psychiatr Serv. 2014;65:675-7.

71. Biringer E, Davidson L, Sundfør B, Ruud T, Borg M. Experiences of support in working toward personal recovery goals: a collaborative, qualitative study. BMC Psychiatry. 2016;16(1):426

72. Tse S, Tsoi EW, Hamilton B, O'Hagan M, Shepherd G, Slade M, et al. Uses of strength-based interventions for people with serious mental illness: a critical review. Int J Soc Psychiatry. 2016;62(3):281-91.

73. Eysenbach G. CONSORT-EHEALTH: Improving and standardizing evaluation reports of Web-based and mobile health interventions. J Med Internet Res. 2011;13(4):e126.

74. Ljungberg A, Denhov A, Topor A. The art of helpful relationships with professionals: a meta-ethnography of the perspective of persons with severe mental illness. Psychiatr Q. 2015;86(4):471-95.

75. Ummel D, Achille M. How not to let secrets out when conducting qualitative research with dyads. Qual health res. 2016 May:26(6):807-15.

\section{Publisher's Note}

Springer Nature remains neutral with regard to jurisdictional claims in published maps and institutional affiliations.

Ready to submit your research? Choose BMC and benefit from:

- fast, convenient online submission

- thorough peer review by experienced researchers in your field

- rapid publication on acceptance

- support for research data, including large and complex data types

- gold Open Access which fosters wider collaboration and increased citations

- maximum visibility for your research: over $100 \mathrm{M}$ website views per year

At BMC, research is always in progress.

Learn more biomedcentral.com/submissions 